\title{
Migrações negras no pós-abolição do sudeste cafeeiro (1888-1940)
}

\author{
Carlos Eduardo Coutinho da Costa*
}

\section{RESUMO}

O presente artigo tem por objetivo analisar o processo de migração de negros - ex-escravos e seus descendentes diretos ou indiretos — do Vale do Paraíba para a Região Metropolitana do Rio de Janeiro, e seus desdobramentos, no período após a promulgação da Lei Áurea. Trata-se de avaliar esse processo para além do sistema dual de explicação das migraçóes: atração versus expulsão. Busca-se, nesse sentido, incorporar análises qualitativas, quantitativas e demográficas dessa experiência. Para atingir tais objetivos utilizou-se o cruzamento de fontes variadas, a saber, os registros civis de nascimento e óbito, censos, entrevistas e bibliografia secundária.

Palavras-chave: pós-abolição; migração; Vale do Paraíba; Baixada Fluminense.

\section{ABSTRACT}

This article focuses on the migration of Blacks - former slaves and their descendants - from the Paraíba Valley to the metropolitan area of Rio de Janeiro, and its consequences, in the post-emancipation period. The goal is to evaluate the process beyond the dual system for explanation of migration: attraction vs. expulsion. We try to incorporate qualitative and demographic analysis of this experience through the intersection of different sources: civil records, census, oral interviews, and secondary literature.

Keywords: post-emancipation; migration; Vale do Paraíba; Baixada Fluminense.

Artigo recebido em 11 de abril de 2014 e aprovado para publicação em 27 de dezembro de 2014.

DOI - http://dx.doi.org/10.1590/2237-101X016030004

A elaboração deste artigo contou com os financiamentos do Projeto Humanidades do CNPq e da Faperj, através da Bolsa Faperj Nota 10.

* Doutor em História Social pela Universidade Federal do Rio de Janeiro (UFRJ) e professor adjunto C1 da Universidade Federal Rural do Rio de Janeiro (UFRRJ). Rio de Janeiro, RJ, Brasil. E-mail: Carlos.hist@gmail.com. 
Durante muitos anos a migração no pós-abolição foi compreendida como um processo de "perda" por parte dos ex-cativos. Ainda se explicava a formação de favelas, guetos e da periferia na cidade do Rio de Janeiro em decorrência da migração de libertados pela Lei Áurea, provenientes do Vale do Paraíba. ${ }^{1}$ Parte da historiografia, da primeira metade do século XX, baseada nas mazelas da "herança da escravidão" e da "anomia social" dos ex-cativos e de seus descendentes, foi a responsável pela construção de uma imagem negativa dessas trajetórias no período do pós-abolição - perpetuadas até os dias de hoje. ${ }^{2}$ Ao contrário dessa afirmação, destaco a importância a ser dada à agência de ex-cativos e de seus descendentes nesse processo. Eles tomaram a migraçáo como um ato consciente e com significado próprio e náo apenas como uma consequência da perda material. Desse modo, a proposta deste artigo é analisar os migrantes como agentes desse processo, dando destaque para os aspectos quantitativos - demográficos - e qualitativos — tais como: os medos, a violência, as esperanças e objetivos - que explicam a migração e a redesenham nesse novo contexto. ${ }^{3}$

Através da análise de registros civis de nascimento e óbito do município de Nova Iguaçu, entrevistas, trajetórias individuais e bibliografia secundária, este artigo investigará, no período do pós-aboliçấo, compreendido entre os anos de 1888 e 1940, parte da experiência de migração de ex-escravos e seus descendentes, diretos ou indiretos, que percorreram o trajeto do Vale do Paraíba para as periferias da cidade do Rio de Janeiro e Regiáo Metropolitana.

\section{A experiência estrangeira}

Para os pesquisadores da Jamaica, Cuba e Estados Unidos, após o fim da escravidáo, libertos e seus descendentes migraram no intuito de experimentar a liberdade. ${ }^{4}$ Em certas localidades, como no Alabama, por exemplo, nos primeiros anos de pós-abolição, boa parte

${ }^{1}$ CARVAlHO, José Murilo de. Os bestializados: o Rio de Janeiro e a República que não foi. São Paulo: Companhia das Letras, 1987. p. 37.

2 Para uma melhor discussão sobre esses olhares historiográficos ver introdução: RIOS, Ana Lugão; MATTOS, Hebe. Memórias do cativeiro: família, trabalho e cidadania no pós-abolição. Rio de Janeiro: Civilização Brasileira, 2005. Em experiência na correção do vestibular da Unicamp, o professor Álvaro Nascimento encontrou respostas dos vestibulandos que reproduziam esse pensamento. Diante desse problema, alinhavou um artigo explicitando os problemas na formação dos alunos do ensino médio sobre a experiência do negro no pos-abolição. Ver: NASCIMENTO, Álvaro. Qual a condição social dos negros no Brasil depois do fim da escravidão? O Pós-abolição no ensino de história. In: SALGUEIRO, Maria Aparecida Andrade (Org.). A República e a questão do negro no Brasil. Rio de Janeiro: Museu da República, 2005. p. 11-26.; INSTITUTO BRASILEIRO DE GEOGRAFIA E ESTATÍSTICA (IBGE). Censos de 1872, 1890 e 1920.

${ }^{3}$ Para uma crítica ao olhar dual das migraçóes, ver: GROSSMAN, James R. Land of hope: Chicago, blacksoutherners, and the great migration. Chicago, IL: University of Chicago Press, 1989. p. 18.

${ }^{4}$ Entre outros: SCOTT, Rebecca. Defining the boundaries of freedom in the world of cane: Cuba, Brazil, and Louisiana after emancipation. The American Historical Review, v. 99, n. 1, p. 70-102, Feb. 1994.; FONER, Eric. O significado da liberdade. Revista Brasileira de História, v. 8, p. 14, 1988; GROSSMAN, James R. Land of hope: Chicago, black southerners, and the great migration, op. cit., p. 21. 
dos ex-escravos abandonou as fazendas e utilizou seu direito de ir e vir, viajando inicialmente entre diversas localidades, sem destino aparente. Nos primeiros meses, após 1865, no sul dos Estados Unidos, muitos jornais noticiaram uma movimentação populacional aparentemente desordenada e não apenas para o norte, como era esperado. De acordo com cronistas da época, "parecia que eles queriam chegar mais perto da liberdade, para então saber o que era isso". Afinal, ter o direito de viajar para onde bem quisesse, durante certo período, foi tido como "fonte de orgulho e excitaçấo para os ex-escravos". ${ }^{6}$ Porém nada parece ter influenciado mais a migraçáo do que a busca pelo reencontro dos parentes separados, pela venda, na escravidáo.

Além do exercício de sua liberdade, muitos buscaram maior independência diante do poder dos proprietários através da conquista da terra e do controle do ritmo e da forma do trabalho. No caso da Jamaica, por exemplo, acreditava-se que os libertos tenderiam a comprar terras baratas e improdutivas para subsistência, distantes das grandes propriedades. Contudo, o que se pôde perceber foi um movimento contrário: de acordo com Holt, eles conseguiram comprar pequenas propriedades, migrando para áreas próximas aos centros urbanos e às áreas agroexportadoras. Desse modo, em suas roças, buscavam aliar uma produção de subsistência com excedentes para a venda em mercados locais, assim como almejavam vender sua força de trabalho nas fazendas de grande porte. Ou seja, dessa estratégia de sobrevivência conseguiam obter três fontes de sobrevivência distintas, ampliando sua independência. ${ }^{8}$

No caso cubano, o lado oriental da ilha atraiu os possíveis migrantes. De acordo com os dados analisados por Rebecca Scott, entre os censos de 1862 e 1899 pôde-se distinguir um novo padrão da distribuição populacional dos negros, localizados agora no Leste. Essa regiâo oferecia um maior acesso à terra, em virtude dos seguintes fatores: uma parte era uma região montanhosa e não propícia à produção açucareira em larga escala, assim como, após a Guerra dos Dez Anos, essas terras foram distribuídas pelo governo para serem ocupadas e revitalizadas. ${ }^{9}$ Nesse sentido, a migraçáo para as cidades foi limitada, pois, segundo Scott,"a proporção da população negra da ilha residente na Província de Havana, por exemplo, não aumentou acentuadamente durante o período de emancipação". ${ }^{10} \mathrm{Da}$ mesma forma, após uma análise de dados estatísticos, a autora afirma que os números "não parecem retratar uma migraçáo em massa para as cidades", ${ }^{11}$ ou seja, as pessoas encontradas, em 1899, nos censos das cidades, eram provavelmente descendentes de população negra urbana residente, e não migrados das antigas fazendas de açúcar.

\footnotetext{
${ }^{5}$ FONER, Eric. O significado da liberdade, op. cit., p. 14.

${ }^{6}$ Ibid.

${ }^{7}$ Ibid.

${ }^{8}$ HOLT, Thomas. The problem of freedom: race, labor, and politics in Jamaica and Britain, 1832-1938.

Baltimore: Johns Hopkins University Press, 1992, principalmente capítulo 5.

9 SCOTT, Rebecca. Emancipação escrava em Cuba: a transição para o trabalho livre, 1860-1889. Rio de Janeiro: Paz e Terra; Campinas: Unicamp, 1991. p. 250.

${ }^{10}$ Ibid., p. 252.

${ }^{11}$ Ibid.
} 
Nos Estados Unidos parte da migração para os centros urbanos ocorreu pela busca de instituiçôes sociais negras, tais como igrejas, escolas e sociedades de ajuda mútua, assim como organizaçôes de ajuda contra a violência, muito comuns nesse período, como o Departamento dos Libertos (Freedman's Bureau). Para Foner, em algumas localidades, as consequências da migração para as cidades foram desastrosas, pois em virtude da falta de trabalho e de dinheiro, esses migrantes passaram a residir nos subúrbios, com pouca higiene e com alta proliferação de doenças. ${ }^{12}$ Porém, entre todas as experiências vivenciadas no pós-aboliçáo pela populaçáo de ex-escravos e seus descendentes, Foner identificou, para o sul dos Estados Unidos, que o destino mais comum foi a permanência nas fazendas nos primeiros anos, trabalhando, agora, em outras condiçôes. ${ }^{13}$

The great migration, como usualmente costumou-se denominar a migração da população de negros livres em direção ao norte dos Estados Unidos, só teve início no século XX, em 1910, com o ápice em 1920, e não nos anos iniciais da pós-emancipação. ${ }^{14}$ Há toda uma bibliografia norte-americana que trabalha as migraçôes sulistas em direção ao norte a partir de vários temas: políticos, sociais, econômicos, não econômicos, raciais e culturais. ${ }^{15}$

\section{A "grande migração" do Brasil}

No caso brasileiro, os primeiros trabalhos sobre a temática da migração de negros no pós-abolição exaltavam as experiências negativas. Ao analisar o município de Rio Claro,

\footnotetext{
${ }^{12}$ FONER, Eric. O significado da liberdade, op. cit., p. 15.

${ }^{13}$ Ibid.

${ }^{14}$ GREGORY, James N. The southern diaspora and the urban dispossessed: demonstrating the census public use microdata samples. The Journal of American History, n. 82, 1995. p. 111-134.

${ }^{15}$ São eles: BERRY, Chad. Southern migrants, northern exiles. Urbana, IL: University of Illinois Press, 2000; GROSSMAN, James R. Land of hope: Chicago, black southerners, and the great migration, 1989, op. cit.; TOLNAY, Stewart E. The great migration and changes in the northern black family, 1940 to 1990. Social Forces, n. 75, p. 1213-1238, 1997; TOLNAY, Stewart E. Migration experience and family patterns in the 'promised land'. Journal of Family History, n. 23, p. 68-89, 1998; TOLNAY, Stewart E. The great migration gets underway: a comparison of black southern migrants and non-migrants in the north, 1920. Social Science Quarterly, p. 235-252, 2001; LIEBERSON, Stanley; WILKINSON, Christy A. A comparison between northern and southern blacks residing in the north. Demography, n. 13, p. 199-224, 1976; LEMANN, Nicholas. The promised land: the great migration and how it changed America. Nova York: Knopf, 1991; JOHNSON, D. M.; REX, R. C. Black migration in America: a social demographic history. Durham, NC: Duke University Press, 1981; HENRI, F. Black migration: movement north, 1900-1920. Garden City, NY: Anchor, 1975; GREGORY, James N. The southern diaspora and the urban dispossessed: demonstrating the census public use microdata samples. The Journal of American History, v. 82, n. 1 p. 111-134, jun. 1995; GREGORY, James N. The southern diaspora: how the great migrations of black and white southerners transformed America. Chapel Hill: University of North Carolina Press, 2005; TROTTER JR., Joe William. The great migration in historical perspective: new dimensions of race, class \& gender. Bloomington e Indianapolis: Indiana University Press, 1991; HARRISON, Alferdteen. Black exodus: the great migration from the American South. Jackson e Londres: University Press of Mississipi, 1991.
} 
Warren Dean percebeu que, na disputa por mercado de trabalho entre imigrantes e nacionais, os negros perderam espaço. Na impossibilidade da inserção social através do trabalho nas fazendas do interior de São Paulo, os ex-cativos foram expulsos e migraram forçosamente para cidades em ascensão, nesse caso, a cidade de Santos, zona portuária. ${ }^{16}$

A explicação mais generalizada e usualmente reproduzida sobre a trajetória de ex-escravos no período pós-abolição baseou-se em notícias alarmantes de jornais e na lógica liberal de modernização do país. A teoria da liberação de mão de obra do campo para as cidades, isto é, a expulsão - para a construção de um exército de reserva, que levaria à futura industrialização do Brasil e as consequências sociais calamitosas desse fato, como a segregação e a favelização — , foi uma das mais utilizadas no mundo inteiro, e por aqui não foi diferente. Para José Murilo de Carvalho, por exemplo, a abolição transformou acentuadamente as características da cidade do Rio de Janeiro, uma vez que "alterou-se a população da capital em termos de número de habitantes, composição étnica, de estrutura ocupacional" ${ }^{17}$ Consequentemente, para Nei Lopes, com a falta de moradias no centro da cidade restaram, como opção, os morros, onde

aos migrantes do Vale do Paraíba que para o Rio de Janeiro continuam vindo desde a falência da lavoura cafeeira na região, aos veteranos da Guerra do Paraguai, os flagelados da grande seca, vêm juntar-se, agora, mais e mais negros, oriundos das diversas regióes do país, mas principalmente das províncias vizinhas. ${ }^{18}$

Ou seja, após 1888, a capital federal passou a ser o centro de atração de mão de obra ociosa do Sudeste, em crise de produção.

Para os autores mencionados, a partir do olhar econômico do processo, somente restou aos migrantes a segregação do trabalho. De acordo com Carvalho, "a abolição lançou o restante da mão de obra escrava no mercado de trabalho livre e engrossou o contingente de subempregados e desempregados" na cidade do Rio de Janeiro, ${ }^{19}$ isto é, na disputa desleal desses trabalhadores migrantes com os residentes da cidade do Rio de Janeiro e imigrantes, o resultado foi a segregaçáo racial, social e espacial. Desse modo, a trajetória negativa dos negros no pós-abolição, para esses autores, estaria ligada, em sua maior parte, a condicionantes econômicos, não levando em conta aspectos culturais, da violência, entre outros.

No entanto, trabalhos mais recentes já demonstraram que a visão negativa da "herança da escravidão" e da "vitimização" — de que o negro por vezes não se coadunava com a

${ }^{16}$ DEAN, Warren. Rio Claro: um sistema brasileiro de grande lavoura, 1820-1920. Rio de Janeiro: Paz e Terra, 1977.

${ }^{17}$ CARVALHO, José Murilo de. Os bestializados: o Rio de Janeiro e a República que não foi, op. cit., p. 16.

${ }^{18}$ LOPES, Nei. O negro no Rio de Janeiro e sua tradiçáo musical: partido-alto, calango, chula e outras cantorias. Rio de Janeiro: Pallas, 1992. p. 3.

${ }^{19}$ CARVALHO, José Murilo. Os bestializados: o Rio de Janeiro e a República que não foi, op. cit., p. 16. 
modernidade em construção ao mesmo tempo que era apenas espectador das novas situaçôes - deixava de lado a agência do ex-escravo, suas vontades e projetos de vida. ${ }^{20} \mathrm{Ou}$ seja, a migração não deve ser vista como resultado do período da escravidão e seu subsequente desmantelamento, mas sim através da ótica da agência do negro no pós-abolição.

Mesmo diante dessa nova perspectiva, deve-se ressaltar que de fato a população do então município neutro aumentou significativamente após 1890 . Se no ano de 1872, incluindo escravos e livres, havia na capital federal 274.972 pessoas, esse número aumentou para 522.651 em 1890, chegando, no ano de 1920, a 1.157 .873 habitantes. ${ }^{21}$ Ou seja, somente na análise superficial desses números é possível atestar um movimento migratório para essa cidade, o que, aparentemente, não ocorreu no imediato pós-abolição, mas sim ao longo da década de 1920. No entanto, nos censos consultados não existem referências às origens dessas pessoas e muito menos às motivaçóes, o que reforça a necessidade da pesquisa em outras fontes capazes de informar esses dados, tais como entrevistas, registros civis de nascimento e de óbito.

Nas entrevistas realizadas com descendentes diretos de ex-escravizados, Ana Rios se deparou com três tipos de trajetórias de vida após a promulgação da Lei Áurea. Na primeira, encontrou histórias de extrema estabilidade. Nos últimos anos da escravidáo no Brasil, na regiấo do Vale do Paraíba, vários proprietários conseguiram manter os libertos nas fazendas, alforriando-os em massa. Tentavam construir "laços de gratidáo" com os trabalhadores, no intuito de organizar um verdadeiro "exército" de trabalhadores negros. ${ }^{22}$ Muitos desses grupos conseguiram permanecer nas fazendas por muitos anos, e vieram a formar o que hoje a Fundação Palmares reconhece como comunidades remanescentes de quilombolas, encontradas na regiáo do Vale do Paraíba. ${ }^{23}$ Além disso, havia os que de alguma forma compraram pequenas propriedades e ali se estabeleceram, trabalhando como meeiros, parceiros, de empreitada, obtendo parte de sua subsistência através das pequenas roças. Em suma, no imediato pós-abolição, a maior parcela dessa população manteve-se no Vale do Paraíba.

Em segundo lugar, a autora encontrou trajetórias daqueles que não conseguiram obter estabilidade: migravam de fazenda para fazenda em busca de trabalhos temporários, e ra-

\footnotetext{
${ }^{20}$ Para uma melhor discussão sobre esses olhares historiográficos ver introdução: RIOS, Ana Lugão; MATTOS, Hebe. Memórias do cativeiro: família, trabalho e cidadania no pós-abolição, 2005, op. cit., introdução; NASCIMENTO, Álvaro. Qual a condição social dos negros no Brasil depois do fim da escravidão? O pós-abolição no ensino de história, op. cit., p. 11-26.

${ }^{21}$ IBGE. Censos de: 1872, 1890, 1920.

${ }^{22}$ MATTOS, Hebe. Das cores do silêncio: significados da liberdade no Brasil escravista. Rio de Janeiro: Nova Fronteira, 1997.

${ }^{23}$ A partir do art. 68 da ADCT de 1988, as comunidades negras, ou "terras de pretos", onde viviam descendentes diretos de ex-escravos, e que sobreviviam do uso coletivo da terra, passaram a ter o direito de desapropriação da mesma. Para uma melhor discussão da lei ver: MATTOS, Hebe. Novos quilombos: ressignificaçóes da memória do cativeiro entre descendentes da última geração de escravos. In: RIOS, Ana Lugão; MATTOS, Hebe. Memórias do cativeiro: família, trabalho e cidadania no pós-abolição. Rio de Janeiro: Civilização Brasileira, 2005; GUIMARÁES, Eliose Silva. Terra de preto: usos e ocupação da terra por escravos e libertos (Vale do Paraíba Mineiro, 1850-1920). Niterói: EdUFF, 2009.
} 
ramente obtinham algum tipo de mobilidade social por conta da sua intensa movimentação. As histórias de vida são marcadas pela violência, instabilidade, pobreza e falta de laços parentais extensos. ${ }^{24}$ Por fim, existiam os que migravam definitivamente para os centros em ascensão. Esse último grupo, formado em sua maioria por filhos e netos, descendentes diretos de ex-escravizados, apenas migrou na década de 1920, quando a condição social e financeira de seus pais não era mais possível de ser reproduzida. ${ }^{25}$ Para os que residiam no campo a erosão do solo, as pragas, a diminuição do emprego por conta da desvalorização do café afetaram muito mais rapidamente o trabalhador no Vale do Paraíba. Provavelmente, para sobreviver tiveram de abrir mão do seu último bem, isto é, a terra. Afinal, toda a área desgastada passou a servir como pasto para o gado, que começava a se tornar a alternativa mais viável economicamente para a regiáo. ${ }^{26}$

Somado a isso, outro elemento, de caráter náo econômico, deve ter afetado diretamente a trajetória dos que desejavam migrar, no imediato pós-abolição, para a cidade do Rio de Janeiro: o medo. É muito provável que os jornais da época tenham tido um papel preponderante no impedimento da migração em massa da população rural para as cidades. Os contatos com jornalistas estrangeiros, principalmente dos Estados Unidos, podem ter incentivado uma preocupação demasiada com esse processo. Afinal, naquele país, a chegada de negros ao Norte provocou disputas violentas no mundo do trabalho, acirrou a segregação racial e aumentou a quantidade de pobres nos centros das cidades. ${ }^{27} \mathrm{O}$ medo, propagado por discursos inflamados e publicados em jornais, pode ter auxiliado a permanência de negros no Vale do Paraíba, no imediato período do pós-abolição. Discursos denunciatórios como o "faltam braços no campo e sobram pernas na cidade", propagados, por exemplo, pelo jornal Correio da Lavoura, no ano de 1917, eram proferidos com o intuito de assegurar aos fazendeiros a mão de obra nacional no Vale do Paraíba. ${ }^{28}$

Pouca ou quase nenhuma atenção foi dada às características sociais e culturais desse processo. Em primeiro lugar, nada deve ter incentivado mais a migração do que o desejo de muitos ex-escravos de reunir famílias separadas havia muito tempo pelo flagelo da época da escravidão.$^{29}$ Um segundo fator a incentivar a migração pode também ter sido a busca de um maior e melhor acesso à educação. Desde o período da escravidão, muitos cativos deixaram, nas cartas de alforria, o desejo de trocar o cativeiro por longos anos de serviço obrigatório em troca de o patrão lhe assistir em caso de doença e, principalmente, dar educação aos seus fi-

\footnotetext{
${ }^{24}$ RIOS, Ana Lugão; MATTOS, Hebe. Memórias do cativeiro: família, trabalho e cidadania no pós-abolição, 2005, op. cit.

${ }^{25}$ Ibid.

${ }^{26}$ FRAGOSO, João. Barôes do café e sistema agrário escravista: Paraíba do Sul/Rio de Janeiro (1830-1888). Rio de Janeiro: 7 Letras, 2013.

${ }^{27}$ GROSSMAN, James R. Land of hope: Chicago, black southerners, and the great migration, 1989, op. cit.

${ }^{28}$ Hebdomanário sediado no atual município de Nova Iguaçu. Correio da Lavoura, 7 maio 1917.

${ }^{29}$ FRAGA, Wealter Filho. Encruzilhadas da liberdade: histórias de escravos e libertos na Bahia (1870-1910). Campinas: Unicamp, 2006. p. 314.
} 
lhos. ${ }^{30}$ Pouco ainda se estudou sobre o acesso da população preta e parda às escolas de ensino básico no Vale do Paraíba; no entanto, nas regiôes periféricas, como a Baixada Fluminense, já existem estudos demonstrando a entrada de professores e alunos negros nas escolas. ${ }^{31}$ É bem possível que boa parte dos jovens tenha optado por migrar em busca de um maior acesso à educação, pois, provavelmente, viam nela uma possibilidade de mobilidade social.

Do mesmo modo, pode-se apontar também a violência como motivadora da migração. Em entrevista a Ana Lugão Rios, Cornélio Cansino contou que quando criança seus familiares foram obrigados a se mudar para a fazenda São José, em Juiz de Fora. Seu pai havia feito uma rocinha na fazenda Sáo Lourenço e, por conta da necessidade de capinar a área, ele acabou faltando ao trabalho de "turma" naquele dia. Para se vingar, o proprietário mandou abrir a porteira de sua rocinha e colocou os bois para comer tudo. Seu tio, preocupado com a situação, os convidou para morar com ele, na Fazenda São José. ${ }^{32}$

Apesar de esse exemplo de violência não demonstrar diretamente qualquer conotação racial, no interior de São Paulo ocorreram casos de assassinatos muito semelhantes aos existentes no sul dos Estados Unidos, no mesmo período. ${ }^{33}$ Ao analisar a correspondência entre o chefe de polícia e o delegado local, em São Carlos, Karl Monsma deparou-se com casos de linchamentos. De acordo com uma das cartas encontradas, um mês e meio após a abolição, 400 pessoas invadiram a delegacia e assassinaram a tiros e pauladas o "liberto Joáo", que havia assaltado uma casa da localidade, dois dias antes. Apesar de nenhum jornal ou mesmo a denúncia policial ter afirmado a ocorrência de estupro, a população local acreditou haver ocorrido, por conta da violência utilizada. E por isso, após ter matado o autor do crime, o ajuntamento de pessoas resolveu pendurá-lo na Praça Matriz da cidade. Somado a esse caso, $\mathrm{o}$ autor encontrou mais três, com histórias muito semelhantes. ${ }^{34}$ Monsma chegou à conclu-

${ }^{30}$ LIMA, Henrique Espada. Sob domínio da precariedade: escravidão e os significados da liberdade de trabalho no século XIX. Topoi, v. 6, n. 11, p. 289-326, jul./dez. 2005.

${ }^{31}$ BEZERRA, Nielson. A cor da Baixada: escravidão, liberdade e pós-abolição no recôncavo da Guanabara. Duque de Caxias, RJ: APPH-CLIO, 2012.

${ }^{32}$ Entrevista de Cornélio Cansino a Ana Lugão Rios, em 1994. As entrevistas encontram-se no Acervo Memórias do Cativeiro (AMC) e encontram-se disponíveis em: <http://www.labhoi.uff.br/narrativas/depoimentos>. Acesso em: 14 mar. 2012.

${ }^{33}$ HENRI, F. Black migration: movement north, 1900-1920, 1975, op. cit.; TOLNAY, Stewart E.; BECK, E. M. Racial violence and black migration in the South, 1910 to 1930. American Sociological Review, v. 57, n. 1, p. 103-116, Feb. 1992; TOLNAY, Stewart E.; BECK, E. M. A festival of violence: an analysis of southern lynchings, 1882-1930. Urbana, IL: University of Illinois Press, 1995; WOOFTER, T. J. Negro problems in cities. Nova York: Doubleday, Doran \& Co., 1928; TOLNAY, Stewart E. The African American 'great migration' and beyond. Annual Review of Sociology, v. 29, p. 209-232, 2003.

${ }^{34}$ MONSMA, Karl. Histórias de violência: inquéritos policiais e processos criminais como fontes para o estudo de relaçôes interétnicas. In: DEMARTINI, Zeila de Brito Fabri.; TRUZZI, Oswaldo M Serra (Orgs.). Estudos migratórios: perspectivas metodológicas. São Carlos: EDUFSCar, 2005. p. 159-221; MONSMA, Karl. Linchamentos raciais depois da abolição: quatro casos do interior paulista. In: CONGRESSO INTERNACIONAL DA LATIN AMERICAN STUDIES ASSOCIATION, XXVIII., 2009, Rio de Janeiro. Anais... Rio de Janeiro: Lasa, 2009. 
são de que, apesar de os linchamentos diminuírem entre 1910 e 1930, quando ocorreram esses casos de violência, a população de negros migrou por conta do medo. ${ }^{35}$

Do mesmo modo, Lucia Helena Silva, através da análise da documentação da Casa de Detenção do Município do Rio de Janeiro, conseguiu identificar a migração dessa população para a então Capital Federal entre os anos de 1890 e 1920. De acordo com a autora, a migraçáo daqueles provenientes do interior do estado de Sáo Paulo estava ligada aos seguintes fatores: fuga da concorrência desleal por empregos com os imigrantes, da falta de terras e do racismo. ${ }^{36}$

É possível, ao longo da década de 1920, que os jornais tenham passado a exercer um papel quase oposto ao citado anteriormente. Com a diminuição da imigração europeia, em parte por conta da Primeira Guerra Mundial, houve um aumento na necessidade de mão de obra na capital e nas periferias, e, logo, os jornais passariam a auxiliar na divulgação de informaçóes das oportunidades de emprego na cidade do Rio de Janeiro e seus arredores. Álvaro Nascimento vem se dedicando à análise de um jornal da Região Metropolitana do Rio de Janeiro, denominado O Correio da Lavoura. ${ }^{37}$ Nas folhas do jornal é possível notar, em várias passagens, sua preocupação com os trabalhadores do Vale do Paraíba, bem como vários anúncios do Ministério da Agricultura, convocando-os. Para além do aumento da oferta de serviços, regióes no entorno da cidade ampliaram suas produçóes, em parte direcionadas para o mercado de abastecimento da cidade e em parte para o mercado externo - como foi o caso dos laranjais em Nova Iguaçu, Campo Grande, Madureira e Cascadura - além das indústrias, com destaque para as fábricas de Bangu. Para nutrir tais empreendimentos de mão de obra, os jornais podem ter exercido papel preponderante na divulgação de informaçóes sobre essas regiôes. Ainda não se sabe se o jornal também era lido no Vale do Paraíba; contudo, através das folhas publicadas, é possível observar uma relação nítida entre essas regiôes.

Para além das informaçôes recebidas via material impresso, as pessoas residentes no Vale do Paraíba tinham notícias da Capital através de parentes e amigos migrantes. No caso dos trabalhadores de Nova Iguaçu, nas primeiras décadas de produção de laranja, eles eram convocados em apenas dois momentos — na plantação e na colheita — , ou seja, migravam sazonalmente para essa região retornando à casa ao fim da atividade. ${ }^{38}$ Sempre foi interessante pensar como as notícias relacionadas com empregos vagos ou terras livres chegavam a locais tão interioranos. Um desses mecanismos foi aberto por Dionísio. Seu neto, Manoel

\footnotetext{
${ }^{35}$ Ibid.

${ }^{36}$ SILVA, Lucia Helena Oliveira. Construindo uma nova vida: migrantes paulistas afrodescendentes na cidade do Rio de Janeiro no pós-abolição (1888-1926). Tese (Doutorado em História) — Universidade Estadual de Campinas, Campinas, 2001.

${ }^{37}$ NASCIMENTO, Álvaro. 13 de Maio: memória da escravidão e educação nas páginas do Correio da Lavoura (Nova Iguaçu, RJ, 1917-1950). In: FORTES, Alexandre. Cruzando fronteiras: novos olhares sobre a história do trabalho. São Paulo: Fundação Perseu Abramo, 2013. p. 205-228.

${ }^{38}$ SOUZA, Sonali Maria de. Da laranja ao lote: transformaçóes sociais em Nova Iguaçu. Dissertação (Mestrado em Antropologia Social) — Museu Nacional, Universidade Federal do Rio de Janeiro, Rio de Janeiro, 1992.
} 
Seabra, residente na Comunidade Sáo José, disse que o avô caminhava durante seis dias do município de Nova Iguaçu até chegar à casa, na cidade de Santa Isabel do Rio Preto, distrito de Valença, no Vale do Paraíba. Em suas viagens, além de trazer presentes, inteirava os parentes dos acontecimentos familiares e do seu novo local de moradia. ${ }^{39}$ Essa prática de troca de informaçôes entre parentes, principalmente as relacionadas com novos ofícios e terras livres, era muito usual entre os camponeses. ${ }^{40}$

Outros trabalhadores que também contribuíram na distribuição de informaçôes foram os ferroviários. As linhas férreas cortavam as fazendas de café, perpassavam a Baixada Fluminense e terminavam no centro da cidade do Rio de Janeiro. José Gomes de Moraes, mais conhecido como Seu Juca, morador do município de Barra do Piraí, trabalhou durante 40 anos no prédio da Central da Estrada de Ferro Dom Pedro II, localizado no centro da cidade do Rio de Janeiro, voltando todos os dias para casa. ${ }^{41}$ Trabalhadores das linhas férreas, ao retornar às suas fazendas de origem, comentavam com os demais parentes e amigos as informaçôes que obtinham no trajeto, aumentando o interesse de futuros migrantes. Do mesmo modo, essa malha de transportes contribuiu para a emigração do Vale do Paraíba; afinal, desde o final do século XIX a ferrovia transportava, além do café para a capital, passageiros.

O processo de migração do Vale do Paraíba para as periferias da cidade do Rio de Janeiro foi captado também em outras fontes de pesquisa. Nas entrevistas do Acervo Memórias do Cativeiro, foi possível encontrar pelo menos duas trajetórias de descendentes de ex-escravizados que optaram por residir na Capital Federal. Cornélio Cansino, nascido em Juiz de Fora, no ano de 1913, afirmou em depoimento que seu tio Cornélio, que na época de sua juventude havia migrado para o estado de São Paulo, anos depois optou por residir no Distrito Federal. Chegando lá encontrou mais dois tios: Ricardo e Geraldo. Todos foram morar no centro da cidade. O tio Cornélio conseguiu uma pequena casa na rua Frei Caneca, enquanto os outros não tiveram a mesma sorte. Ricardo e Geraldo moravam no morro do Catumbi, na rua São Carlos, atual favela São Carlos. ${ }^{42}$

Apesar de esses exemplos demonstrarem a possibilidade de moradia bem próxima ao grande centro urbano, a maior parte dos migrantes descendentes diretos ou indiretos de ex-escravizados parece ter ocupado regióes periféricas. Na Bahia, por exemplo, Walter Fraga Filho conseguiu acompanhar uma migração de libertos para Região Metropolitana de Salvador, mas não avançou, pois encontrou poucas trajetórias. ${ }^{43}$ Já em outras regióes, como, por exemplo, o Paraná, de acordo com Leonardo Marques, os ex-escravos migraram para as

\footnotetext{
${ }^{39}$ Entrevista de Manoel Seabra, 2003 (AMC).

${ }^{40}$ MARTINS, J. S. O tempo da fronteira: retorno à controvérsia sobre o tempo histórico da frente de expansão e da frente pioneira. Tempo Social: revista de Sociologia da USP, São Paulo, v. 8, n. 1, p. 25-70, maio 1996.

${ }^{41}$ Entrevista de Seu Juca, 2006. (Acervo UFF Petrobras Cultural de Memória e Música Negra - AMMN).

${ }^{42}$ Entrevista de Seu Cornélio Cansino, 1995 (AMC).

${ }^{43}$ FRAGA, Walter Fraga. Encruzilhadas da liberdade: histórias de escravos e libertos na Bahia (1870-1910). Campinas: Unicamp, 2006.
} 
cidades mais próximas que ainda eram marcadas por um misto de área rural com a urbanização em crescimento. ${ }^{44} \mathrm{Ou}$ seja, em comparação a esses movimentos, mesmo que o destino fosse o centro urbano, essa primeira geração de migrantes, provavelmente, estabilizou-se socialmente nas regióes do entorno, uma vez que ali estavam as lavouras e as áreas de criação de animais, destinadas ao abastecimento alimentar da cidade. Conhecedores do trabalho braçal no campo, é possível que ali tenham encontrado seus primeiros empregos.

Não há pesquisas que apontem numericamente a quantidade, origem, local de moradia e ofícios dos migrados. E as poucas pesquisas sobre o trabalho dos negros no centro da cidade não conseguiram identificar a origem dos mesmos. Fabiane Popinigis, ao analisar os processos-crimes, se debruçou sobre o ofício dos comerciantes e de seus empregados no centro da cidade do Rio de Janeiro, no período da Primeira República. Apesar de ter encontrado uma parcela considerável de trabalhadores negros no comércio, não há informações sobre a origem deles. ${ }^{45} \mathrm{O}$ mesmo parece ter sido o caso de Velasco e Cruz ao pesquisar os estivadores de café no porto do Rio de Janeiro. Mesmo tendo analisado as fichas dos sindicalizados, em sua maioria pretos e pardos, não há, pelo menos em suas pesquisas publicadas, qualquer indício de migrantes do Vale do Paraíba. ${ }^{46}$ Entre os marinheiros da Armada, Álvaro Nascimento também não conseguiu identificar migrantes originários do vale do café. ${ }^{47} \mathrm{E}$ mesmo na análise das associações de trabalhadores recém-ingressados após a abolição, Marcelo Mattos tampouco encontrou os migrados. ${ }^{48}$

A partir das questóes levantadas, o próprio crescimento do subúrbio e da Baixada Fluminense pode ser repensado, não sendo apontado como um resultado direto da reforma Pereira Passos e consequente expulsão da população pobre do centro da capital federal, como afirmava José Murilo de Carvalho. ${ }^{49}$ Rafael Mattoso, por exemplo, demonstrou que o crescimento dessas regiôes foi conectado à dinâmica própria de atração e não apenas um resultado

\footnotetext{
${ }_{44}$ MARQUES, Leonardo. Por aí e por muito longe: dívidas, migraçóes e os libertos de 1888. Rio de Janeiro: Apicuri, 2009. p. 102-103.

${ }_{45}$ POPINIGIS, F. Proletários de casaca: trabalhadores no comércio (Rio de Janeiro, 1850-1920). Campinas: Unicamp, 2007.

${ }^{46}$ CRUZ, Maria Cecília Velasco e. Tradições negras na formação de um sindicato: Sociedade de Resistência dos Trabalhadores em Trapiche e Café, Rio de Janeiro, 1905-1930. Afro-Ásia, n. 24, p. 243-290, 2000.

${ }^{47}$ NASCIMENTO, Álvaro. A ressaca da marujada: recrutamento e disciplina na Armada Imperial. Rio de Janeiro: Arquivo Nacional, 2001.

${ }^{48}$ MATTOS, Marcelo Badaró. Escravizados e livres: experiências comuns na formação da classe trabalhadora carioca. Rio de Janeiro: Bom Texto, 2008; MATTOS, Marcelo Badaró. Trajetórias entre fronteiras: o fim da escravidão e o fazer-se da classe trabalhadora no Rio de Janeiro. Revista Mundos do Trabalho, v. 1, n. 1, p. 51-64, jan./jun. 2009.

${ }^{49}$ De acordo com Carvalho "a populaçáo que se comprimia nas áreas afetadas pelo bota-abaixo de Pereira Passos teve ou de apertar-se mais no que ficou intocado, ou de subir os morros adjacentes, ou de deslocar-se para a Cidade Nova e para os subúrbios da Central" (CARVALHO, José Murilo de. Os bestializados: o Rio de Janeiro e a República que não foi, op. cit., p. 40).
} 
da expulsão de pessoas do centro do Rio de Janeiro. ${ }^{50} \mathrm{O}$ bairro de Madureira, por exemplo, suscitava interesse da população por conta do seu amplo comércio, enquanto Bangu crescia demograficamente em virtude da característica fabril. ${ }^{51}$

A migração não é um fenômeno exclusivo das sociedades em desenvolvimento, uma vez que sociedades pré-industriais também a experimentaram. A movimentação de camponeses no Brasil foi uma constante desde os primeiros séculos e não ocorreu apenas após a abolição. Sheila de Castro Faria dedicou alguns capítulos em sua tese à migração de livres no interior do Brasil. ${ }^{52} \mathrm{~A}$ autora conseguiu identificar, por exemplo, que a migração entre descendentes de libertos era notória nos séculos XVIII e XIX. Do mesmo modo, Carlos Lima percebeu que "é perceptível uma tendência dos homens não brancos livres e libertos emigrar. [...]" ${ }^{53}$ Para o autor, migraram para regiôes onde havia a possibilidade de contrair matrimônio, aliada à possibilidade de obtenção de terra. ${ }^{54}$

Outro dado que deve ser analisado é o custo da migração. Para aquele que decide migrar, em primeiro lugar, há o desconhecido. Por mais que pessoas de outras regiốes tenham vindo até a fazenda propor um trabalho em outro município, ou mesmo que notícias de jornais deem conta de empregos em diversas regiões do estado, a decisão de migrar é coletiva, familiar e normalmente dispendiosa. Basta lembrar que não há qualquer indício ou informação do quanto será necessário gastar até receber o primeiro salário. A segunda e a terceira geraçôes de migrados possivelmente não sofriam do mesmo problema. $\mathrm{O}$ custo da mudança dessas duas gerações é sempre menor, pois o que migrou primeiro tende a ter uma condição de vida melhor, já conhece onde estão os empregos, volta para o local de origem e coopta apenas aqueles para os quais ele sabe que encontrará ocupação, e, por fim, cede sua casa para um primeiro momento. Tudo isso pode diminuir o custo das geraçôes posteriores de migrados.

Pouco ou quase nada se sabe sobre o custo real da primeira, segunda ou terceira geraçáo de migrados. E por isso devem também ser levados em conta os fracassos, pois apesar de algumas pessoas terem sucesso, nem sempre a migração ocorria como planejado. Dona Florentina Seabra, irmã de Manoel, nascida no ano de 1920, conta que durante sua infância, seu tio Hermegildo foi para Nova Iguaçu e por lá casou. Ficou pouco tempo casado, pois sua esposa acabou largando-o. De acordo com a depoente, após o acontecido "endoideceu e voltou pra cá. Aí ficou aí com a gente". ${ }^{55}$

\footnotetext{
${ }^{50}$ MATOSO, Rafael. Echos de resistência suburbana: uma análise comparativa das contradiçôes socioespaciais cariocas a partir das experiências dos moradores da Freguesia de Inhaúma (1900-1903). Dissertação (Mestrado) - Universidade Federal do Rio de Janeiro, Rio de Janeiro, 2009.

${ }^{51}$ MARTINS, Ronaldo Luiz. Mercadão de Madureira: caminhos do comércio. Rio de Janeiro: Condomínio do Entreposto Mercado do Rio de Janeiro, 2009.

${ }^{52}$ FARIA, Sheila de Castro. A colônia em movimento: fortuna e família no cotidiano colonial. Rio de Janeiro: Nova Fronteira, 1998. p. 111-112.

${ }^{53}$ LIMA, Carlos A. M. Pequena diáspora: migrações de libertos e de livres de cor (Rio de Janeiro, 1765-1844).

Locus: Revista de História, Juiz de Fora, v. 6, n. 2, p. 99-110, 2000.

${ }^{54}$ Ibid., p. 109.

${ }^{55}$ Entrevista de Florentina Seabra, 2003. (AMC).
} 


\section{Migração para a região metropolitana}

Vô Dionísio, assim denominado pelos três netos entrevistados, saiu da Fazenda São José da Serra, nos primeiros anos após a abolição, e fez uma "rocinha" na propriedade ao lado, denominada "empreitada", ambas localizadas no município de Valença, na região do Vale do Paraíba fluminense. Ali criou e casou boa parte de seus filhos. De acordo com o neto, Manoel Seabra, "ele era carreiro e tinha as pernas tortas de tanto carregar peso". ${ }^{56}$ Além disso, "Dionísio era maestro e tocava clarinete, mas é lembrado por netos e bisnetos como um homem terrível, que tratava os filhos com mão de ferro, a figura típica do 'pai senhor"'. 57 Seus descendentes não tiveram as mesmas oportunidades de trabalho e de acesso à terra. Ao longo dos anos de 1920, os filhos homens de Dionísio, nascidos após a abolição, Manoel (20/1/1899), José (23/9/1903) e Joaquim (3/3/1908), abandonaram a fazenda para trabalhar na plantação e colheita de laranja, no antigo município de Iguassu, localizado na Baixada Fluminense. ${ }^{58} \mathrm{E}$ após longas investidas na região, retornaram para levar seus irmãos mais novos. ${ }^{59}$

Seguindo o procedimento de investigar as trajetórias de descendentes diretos de ex-escravos do Vale do Paraíba, foram analisadas as informaçóes de 16 entrevistas, arquivadas no Laboratório de História Oral e Imagem da UFF, realizadas entre 1994 e 2001, por Ana Lugão Rios. A fim de produzir uma amostra significativa de indivíduos, foram contabilizadas todas as pessoas mencionadas nos relatos - exceto as que morreram na infância ou adolescência - e foram considerados como migraçáo apenas os deslocamentos duradouros para fora do município onde o antepassado escravo vivera. Os depoimentos foram coletados em diversos municípios do Vale do Paraíba e proximidades - Valença, Paraíba do Sul, Bananal, Juiz de Fora e Bias Fortes. A partir dessas entrevistas genealógicas, foram contabilizadas 466 pessoas mencionadas, todas nascidas entre os anos de 1850 a 1959. Desse total, 137 (29,4\%) migraram do município de origem, em contraposição aos que tiveram como opção a permanência: 329 (70,6\%).

Apesar de a estabilidade ter sido a norma entre os que vivenciaram a passagem da escravidáo para a liberdade, como visto anteriormente, de acordo com as entrevistas, boa parte dos nascidos entre 1850 e 1869 experimentaram algum tipo de migração. Nesse primeiro corte,

\footnotetext{
${ }^{56}$ A genealogia familiar qualitativa de Dionísio foi construída a partir de três entrevistas realizadas com seus netos moradores da Comunidade de Remanescentes de Quilombos de São José da Serra: Dona Zeferina (1995); Manoel Seabra (1998, 2003 e 2005); e Florentina Seabra do Nascimento (2003 e 2006) — publicada em MATTOS, Hebe. Marcas da escravidão: biografia, racialização e memória do cativeiro na história do Brasil. Tese (Professor Titular) — Departamento de História, Universidade Federal Fluminese, Niterói, 2004. ${ }^{57}$ Ibid.

${ }^{58} \mathrm{O}$ antigo município de Iguassu compreendia os atuais municípios emancipados de: Japeri, Duque de Caxias, Nova Iguaçu, São João de Meriti, Queimados, Nilópolis, Mesquita e Belford Roxo.

${ }^{59}$ Manoel: livro IV, fl. 181, termo 8 - novembro de 1898. Arquivo Eclesiástico de Santa Isabel do Rio Preto (Aesirp); José: livro V, fl. 37, termo 4- 23 de setembro de 1903, Aesirp; Joaquim: livro V, fl. 89, termo 73 - 3 de março de 1908, Aesirp.
} 
notou-se que em sua maioria eram homens, provavelmente solteiros, que se enquadravam na primeira tipologia de Ana Rios, ou seja, migraram dentro do interior do Estado, de fazenda para fazenda. ${ }^{60}$

A migração definitiva, para regiôes metropolitanas e periféricas da cidade do Rio de Janeiro, esteve mais presente nas trajetórias de vida dos nascidos após 1888 . De acordo com os depoimentos coletados, esse fenômeno iniciou-se em meados da década de 1920, tendo o ápice em 1930 e finalizado em meados de 1940. A maioria dos migrantes era do sexo masculino, e no auge do processo de migração, 1930, tinham entre 10 e 30 anos, exatamente as idades de Manoel, José e Joaquim, filhos de Dionísio. Isso significa dizer que os homens nascidos entre os anos de 1900 e 1919, provavelmente, não encontraram as mesmas condiçóes de vida dos ancestrais nas fazendas de café em sua fase jovem, e por isso optaram pela estratégia da migração definitiva, como apontado anteriormente por Ana Rios. Já as mulheres migrantes são mais expressivas entre as nascidas nos anos de 1910-19 e 1920-29. Muitas delas, a exemplo de Leonor, outra entrevistada pela autora, migraram seguindo parentes. ${ }^{61}$ Desse modo, apesar do número maior de homens migrando, preliminarmente se supóe que as mulheres também migraram após a estabilizaçáo dos cônjuges e/ou parentes do sexo masculino.

A Baixada Fluminense, Região Metropolitana do Rio de Janeiro, aparece como o destino preferido dos filhos e netos de ex-escravos do Vale do Paraíba. De acordo com as entrevistas anteriormente mencionadas, das pessoas que tiveram alguma experiência de deslocamento em sua trajetória, 39,4\% não tiveram um destino específico, espalhando-se quase sempre por centros em ascensão como, por exemplo, a cidade mineira de Juiz de Fora; todavia, as 60,6\% restantes direcionaram-se para a Baixada. ${ }^{62}$

Tomando mais uma vez a década de 1930 como o momento de ápice da migração para essa regiáo, entre os mais idosos, nascidos entre 1850 e 1879, e que provavelmente vivenciaram a escravidão, $100 \%$ dos que tiveram alguma experiência de migraçáo foram para a Baixada Fluminense. Semelhante trajetória foi vivenciada por Dionísio e sua esposa, Zeferina. Após seus filhos se estabilizarem em Cabuçu — bairro do município de Nova Iguaçu — eles se mudaram para a Baixada Fluminense com idades avançadas, pois, como apontam seus netos, ali havia facilidades geradas pelo crescimento urbano, como, por exemplo, o Hospital de Iguassu. ${ }^{63}$ No entanto, é a migração de jovens a que mais chama atenção. Foram os nascidos entre 1900 e 1929 que mais optaram por residir na Baixada Fluminense. Como a experiência de migração geralmente ocorria quando essas pessoas estavam ou em fins da adolescência ou, o mais comum, em torno dos 20 anos, pode-se dizer que os nascidos entre 1890 e 1929 incrementaram as migraçóes para a Baixada entre 1910-1949, caindo significativamente esse movimento nas décadas de 1950 e 1960 entre os nascidos entre 1930 e 1949.

\footnotetext{
${ }^{60}$ Podem estar inseridos na primeira trajetória de migração apontada por Ana Rios anteriormente.

${ }^{61}$ Entrevista de Izaquiel Inácio (AMC).

${ }^{62}$ Acervo Memórias do Cativeiro (AMC).

${ }^{63}$ Entrevista de Florentina Seabra (AMC).
} 
Se, ao longo das primeiras décadas da recém-inaugurada República, os jovens descendentes de escravos do Vale do Paraíba encontravam dificuldades em obter empregos nessa região, em virtude da desvalorização do café no cenário internacional e da entrada maciça de criação de gado e plantação de eucalipto - que necessitava cada vez menos de mão de obra - a Baixada Fluminense começava a exportar suas primeiras laranjas. A produção de cítricos, em pequenas chácaras, começou timidamente na década de 1920, tendo seu auge em fins de 1940. ${ }^{64}$ De acordo com o censo do mesmo ano, em Nova Iguaçu, entre as 1.529 propriedades, havia 1.398 estabelecimentos rurais declarados como produtores de laranjas. Isso significa dizer que $92 \%$ das propriedades localizadas no município estavam direcionados a essa produção. ${ }^{65}$ Em comparação a outras atividades, a laranja demonstrou um crescimento significativo na tonelagem de produção em sete anos, sem contar a valorização em sua importância econômica no Estado. ${ }^{66}$ Os incentivos às exportaçôes de laranja tiveram início na década de 1920, momento no qual a economia fluminense necessitava se reerguer economicamente após o declínio na produção de café. ${ }^{67}$ Em virtude do crescimento urbano, aliado aos incentivos governamentais tanto na política de saneamento quanto no incentivo à exportação, tornou-se necessário cooptar mão de obra para fazer subsistir esse novo empreendimento. ${ }^{68}$

No final da Primeira República, ocorreu uma migração em massa para o antigo município de Iguassu. Em comparação aos municípios do Vale do Paraíba, o crescimento demográfico da Baixada Fluminense foi vultoso. De acordo com o gráfico 1, no recenseamento de 1872 havia, na regiáo, 31.251 pessoas, o que náo mudou drasticamente para o seguinte, de 1920, que contabilizou 33.396. No Relatório de Estatística Econômica e Financeira do Estado do Rio de Janeiro, de 1931, a população de Nova Iguaçu atingiu o número de 42.408 habitantes. ${ }^{69}$ Como visto, a partir da década de 1920 já é possível apontar um aumento demográfico no município de Nova Iguaçu. Contudo, o maior salto aconteceu na década seguinte, no censo de 1940, quando se verificou um crescimento populacional de mais de $300 \%$ em apenas 20 anos. $^{70}$

\footnotetext{
${ }^{64}$ PEREIRA, Waldick. Cana, café e laranja: história econômica de Nova Iguaçu. Rio de Janeiro: FGV, 1977. p. 115.

${ }^{65}$ IBGE. Censo de 1940.

${ }^{66}$ Jornal Correio da Lavoura, 4 mar. 1937, apud NASCIMENTO, Álvaro. Francisco Madeira, a visibilidade de um comerciante negro no pós-abolição: economia e mobilidade em Nova Iguaçu. In: SIMPÓSIO NACIONAL DE HISTÓRIA, XVII. 2013. Natal, RN. Anais... São Paulo: Anpuh, 2013.

${ }^{67}$ PEREIRA, Waldick. Cana, café e laranja: história econômica de Nova Iguaçu, op. cit., p. 115.

${ }^{68}$ SOUZA, Sonali Maria de. Da laranja ao lote: transformaçôes sociais em Nova Iguaçu, 1992, op. cit.

${ }^{69}$ Ibid.

${ }^{70}$ Censos IBGE: 1872, 1920, 1940.
} 


\section{Gráfico 1}

População por ano segundo os censos. Paraíba do Sul, Valença, Vassouras e Iguassu.

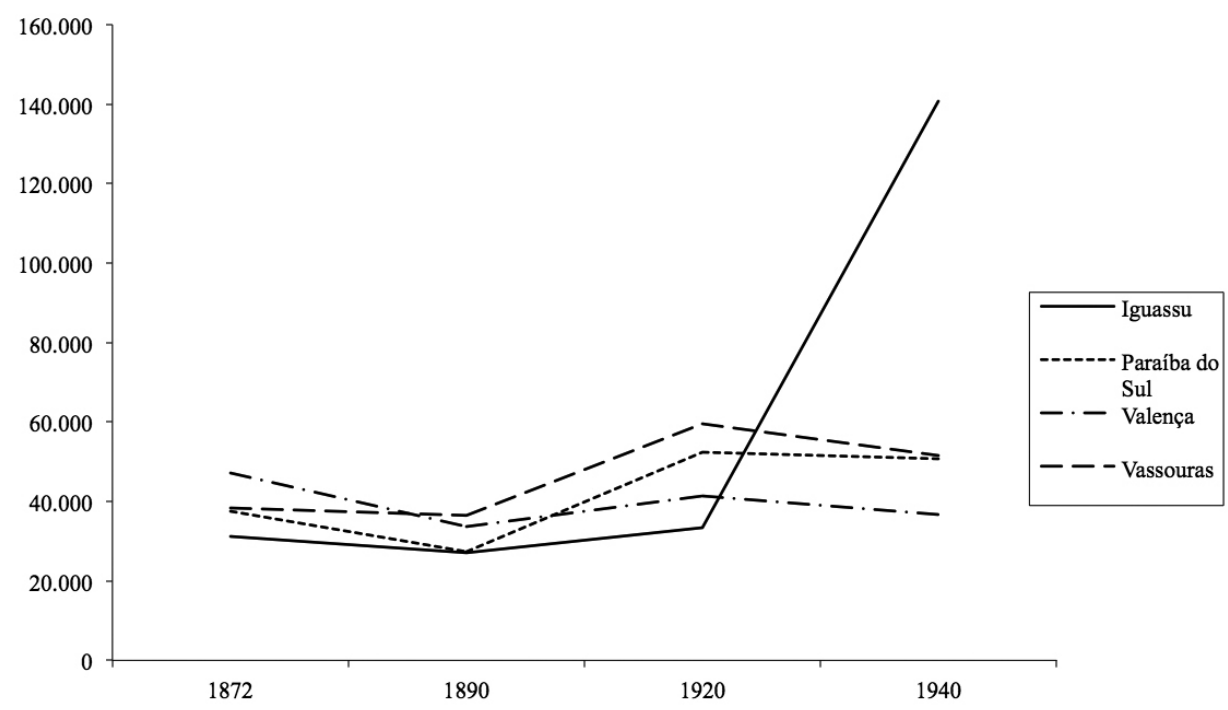

Fonte: IBGE. Censos de 1872, 1890, 1920 e 1940.

Na década de 1920 a população da Baixada Fluminense aumentou significativamente, e, concomitantemente, os dados dos registros civis de nascimento e de óbitos expressaram esse mesmo processo. De acordo com o gráfico 2, nota-se que, apesar da existência de sub-registros - problema enfrentado até os dias de hoje no Brasil — no município de Nova Iguaçu a busca pelo registro de nascimento aumentou a partir do ano de 1914. A partir dessa fonte, de todo modo, é possível levantar alguns indícios da configuração e movimentação populacional no Sudeste.

Entre os registros civis de nascimento pesquisados, encontrei três tipos. O primeiro é o realizado dentro do prazo estipulado por lei, ou seja, até 60 dias contados a partir do nascimento da criança. ${ }^{71} \mathrm{O}$ segundo relaciona-se às crianças registradas tardiamente, incentivadas por novas legislaçóes que anulavam multas incididas sobre o atraso. E por último, os registros de pessoas que durante a adolescência ou na fase adulta procuraram o cartório espontaneamente e declararam seu nascimento. ${ }^{72}$

\footnotetext{
${ }^{71}$ Para uma melhor leitura das leis que regiam o registro civil no Brasil após 1889, ver: SENRA, Nelson de Castro. História das estatísticas brasileiras. Rio de Janeiro: IBGE, 2006. v. 2.

${ }^{72}$ No dia 18 de fevereiro de 1931, o Decreto no 19.710 tornou obrigatórios os registros de nascimentos, não exigindo pagamento de multas nem, tampouco, a necessidade de qualquer justificativa para o registro tardio. Nos anos de 1934 e 1939, foram coletados 540 registros que mencionavam esse decreto. No entanto, nada parece ter incentivado mais a procura pelo registro civil do que o Decreto no 1.116 , de 24 de fevereiro de 1939, pois somente nesse ano foram realizados 1.187 registros tardios.
} 
Gráfico 2

Registros civis de nascimentos e óbitos em números absolutos. Município de Nova Iguaçu, 1889-1939.

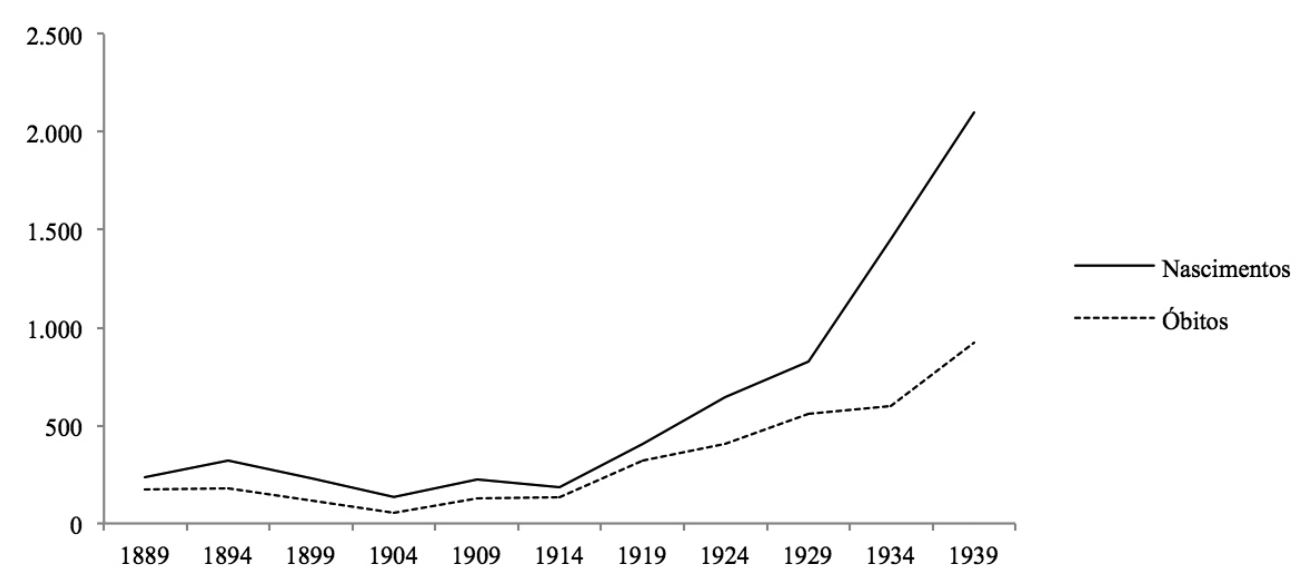

Fonte: $1^{\circ}$ Ofício de Registro Civil de Pessoas Naturais do Município de Nova Iguaçu.

No primeiro caso, das crianças registradas no tempo correto, as informaçóes referentes ao local de nascimento do pai e da mãe não são tão precisos. Por exemplo, se o pai e/ou mãe nasceram na regiáo Norte, Sul ou do Vale do Paraíba do estado do Rio de Janeiro, é apenas declarada sua naturalidade como sendo "neste estado". Todavia, o mesmo não ocorre com os registros tardios, compreendendo os de crianças e os "autodeclarados". ${ }^{73}$ A riqueza de detalhes do segundo e do terceiro tipos de registros é superior à do primeiro, uma vez que informam, além do local preciso de nascimento, as profissões exercidas na Baixada (no caso do terceiro). Em virtude dessas qualidades, neste artigo, tanto os registros tardios quantos os "autodeclarados" compôem a amostra que permitiu a análise da migração dos trabalhadores pretos e pardos.

Entre o rol de pessoas registradas tardiamente no cartório de Nova Iguaçu, boa parte era proveniente de diversos municípios e, inclusive, de outros estados. Entre os anos de 1889 e 1939, dos 957 registros de nascimentos tardios de crianças, 340 (35\%) foram declaradas como nascidas fora do município (tabela 1$) \cdot{ }^{74}$ As crianças declaradas como brancas haviam nascido principalmente, nessa ordem, na capital federal, nos municípios que compóem o

\footnotetext{
${ }^{73} \mathrm{Na}$ falta de uma terminologia específica, neste artigo, optou-se por denominar as pessoas que buscaram registrar o próprio nascimento nos cartórios como "autodeclarados". Mesmo com a presença do registrado no cartório, não é possível afirmar se a cor assentada foi declarada por ele ou apenas assinalada de forma "arbitrária” pelo cartorário. Contudo, o que torna essa documentação importante é a ação do indivíduo na busca do primeiro registro de identidade civil.

${ }^{74}$ Infelizmente, em virtude da natureza do registro, não é possível localizar a origem dos pais, uma vez que esse dado normalmente não é informado. Portanto, em registros de crianças nascidas na Baixada, não há referência ao local específico do nascimento do pai.
} 
Tabela 1

Regiẫo de nascimento das crianças migrantes (\%) registradas tardiamente na Baixada Fluminense, de acordo com a cor. Município de Nova Iguaçu, 1919-1939.

\begin{tabular}{|c|c|c|c|c|c|c|c|c|c|}
\hline & & \multicolumn{2}{|c|}{ Branca } & \multicolumn{2}{|c|}{ Parda } & \multicolumn{2}{|c|}{ Preta } & \multicolumn{2}{|c|}{ Total geral } \\
\hline & & Abs. & $\%$ & Abs. & $\%$ & Abs. & $\%$ & Abs. & $\%$ \\
\hline \multirow{5}{*}{$\begin{array}{l}\text { Regióes do } \\
\text { país }\end{array}$} & Norte & 4 & 2,4 & - & - & - & - & 4 & 1,2 \\
\hline & Centro-Oeste & - & - & - & - & - & - & - & - \\
\hline & Nordeste & 25 & 14,9 & 3 & 2,7 & - & - & 28 & 8,2 \\
\hline & Sul & - & - & - & - & - & - & - & - \\
\hline & Subtotal 1 & 29 & 17,3 & 3 & 2,7 & - & - & 32 & 9,4 \\
\hline \multirow{4}{*}{$\begin{array}{l}\text { Estados do } \\
\text { Sudeste }\end{array}$} & Minas Gerais & 7 & 4,2 & 7 & 6,2 & 9 & 15,0 & 23 & 6,7 \\
\hline & Espírito Santo & - & - & 2 & 1,8 & - & - & 2 & 0,6 \\
\hline & São Paulo & 3 & 1,7 & 5 & 4,5 & - & - & 8 & 2,3 \\
\hline & Subtotal 2 & 10 & 5,9 & 14 & 12,5 & 9 & 15,0 & 33 & 9,6 \\
\hline \multirow{5}{*}{$\begin{array}{c}\text { Estado } \\
\text { do Rio de } \\
\text { Janeiro }\end{array}$} & Capital federal & 55 & 32,7 & 29 & 25,9 & 8 & 13,4 & 92 & 27,1 \\
\hline & $\begin{array}{l}\text { Região Metropoli- } \\
\text { tana e interior }\end{array}$ & 20 & 11,9 & 10 & 8,9 & 4 & 6,6 & 34 & 10,0 \\
\hline & Vale do Paraíba & 54 & 32,2 & 56 & 50,0 & 39 & 65,0 & 149 & 43,9 \\
\hline & Subtotal 3 & 129 & 76,8 & 95 & 84,8 & 51 & 85,0 & 275 & 81,0 \\
\hline & Total geral & 168 & 100 & 112 & 100 & 60 & 100 & 340 & 100 \\
\hline
\end{tabular}

Fonte: $1^{\circ}$ Ofício de Registro de Pessoas Naturais do Município de Nova Iguaçu.

Vale do Paraíba e no Nordeste. ${ }^{75}$ Tanto as crianças pardas quanto as pretas eram majoritariamente naturais do Vale do Paraíba, com uma boa parcela também do Distrito Federal, seguindo-se o estado de Minas Gerais e apenas três pardos do Nordeste. Dos que vieram de outros estados, destaca-se o percentual identificado como brancos vindos do Nordeste. Desse modo, esses registros demonstram não apenas uma migração familiar, mas também que elas provinham principalmente do interior do estado do Rio de Janeiro, sendo que entre pardos e negros o percentual dos originários do Vale é o mais relevante para este artigo.

E qual é a origem dos migrantes jovens e adultos que optaram residir na região da Baixada Fluminense? Na tabela 2 encontram-se os dados referentes às pessoas que buscaram o registro civil para declarar seu próprio nascimento, os “autodeclarados”. Nela, é possível notar que, independentemente da cor, o Vale da Paraíba aparece como o principal local de origem. Aqueles registrados como brancos e pardos provinham principalmente, nesta

\footnotetext{
${ }^{75}$ Apesar da possível variação semântica das categorias de cor — "branca", "pardo" e "preto" — ao longo de 50 anos, neste artigo optei por utilizá-las como são apresentadas na documentação. Para uma melhor discussão sobre a mudança de significados, ao longo dos anos, ver: CORREIA, Margarita. A discriminação racial nos dicionários de língua: tópicos para discussão, a partir de dicionários portugueses contemporâneos. Revista Alfa. v. 50, n. 2, p. 155-171, jul./dez. 2006.
} 
Tabela 2

Região de Nascimento dos "autodeclarantes" migrados para a Baixada Fluminense. Município de Nova Iguaçu, 1919-1939.

\begin{tabular}{|c|c|c|c|c|c|c|c|c|c|}
\hline & & \multicolumn{2}{|c|}{ Branca } & \multicolumn{2}{|c|}{ Parda } & \multicolumn{2}{|c|}{ Preta } & \multicolumn{2}{|c|}{ Total } \\
\hline & & Abs. & $\%$ & Abs. & $\%$ & Abs. & $\%$ & Abs. & $\%$ \\
\hline \multirow{5}{*}{ Regiôes do país } & Norte & 4 & 1,6 & 3 & 1,3 & - & - & 7 & 1,1 \\
\hline & Centro-Oeste & 1 & 0,4 & 1 & 0,4 & - & - & 2 & 0,3 \\
\hline & Nordeste & 72 & 29,1 & 52 & 22,4 & 5 & 3,4 & 129 & 20,6 \\
\hline & Sul & 3 & 1,2 & 2 & 0,9 & 1 & 0,7 & 6 & 1,0 \\
\hline & Subtotal 1 & 80 & 32,3 & 58 & 25,0 & 6 & 4,1 & 144 & 23,0 \\
\hline \multirow{4}{*}{$\begin{array}{l}\text { Estados do } \\
\text { Sudeste }\end{array}$} & Minas Gerais & 17 & 6,9 & 17 & 7,3 & 11 & 7,5 & 45 & 7,2 \\
\hline & Espírito Santo & 2 & 0,8 & 1 & 0,4 & 3 & 2,1 & 6 & 1,0 \\
\hline & São Paulo & 6 & 2,4 & 3 & 1,3 & - & - & 9 & 1,4 \\
\hline & Subtotal 2 & 25 & 10,1 & 21 & 9,0 & 14 & 9,6 & 60 & 9,6 \\
\hline \multirow{5}{*}{$\begin{array}{l}\text { Estado do Rio } \\
\text { de Janeiro }\end{array}$} & Capital federal & 36 & 14,6 & 31 & 13,4 & 6 & 4,1 & 73 & 11,6 \\
\hline & $\begin{array}{l}\text { Região Metropolita- } \\
\text { na e interior }\end{array}$ & 29 & 11,8 & 27 & 11,7 & 18 & 12,2 & 74 & 11,8 \\
\hline & Vale do Paraíba & 77 & 31,2 & 95 & 40,9 & 103 & 70,0 & 275 & 44,0 \\
\hline & Subtotal 3 & 142 & 57,6 & 153 & 66,0 & 127 & 86,3 & 422 & 67,4 \\
\hline & Total geral & 247 & 100 & 232 & 100 & 147 & 100 & 626 & 100 \\
\hline
\end{tabular}

Fonte: $1^{\circ}$ Ofício de Registro de Pessoas Naturais do Município de Nova Iguaçu.

ordem, de municípios do Vale do Paraíba, da região Nordeste, da capital federal e de outras localidades do interior do estado do Rio de Janeiro. Já os migrantes identificados no registro civil como pretos eram originários principalmente, nesta ordem, de municípios do Vale do Paraíba, de outros municípios do interior do estado do Rio de Janeiro, e de Minas Gerais. No conjunto, portanto, as correntes migratórias para a Baixada eram basicamente duas: do próprio Sudeste - principalmente o Vale do Paraíba - e do Nordeste.

Desde o final do século XIX a população do sertão nordestino sofreu com intensos períodos de seca. Migraram para diversas áreas, primeiro para a região Norte e, posteriormente, incentivados pelo governo, mudaram-se para o Sudeste. ${ }^{76}$ Como se observa nas tabelas, mui-

\footnotetext{
${ }^{76}$ Há toda uma gama de bibliografia que se dedica ao tema, ver: GRAHAM, D. H.; FILHO, S. B. H. Migraçôes internas no Brasil (1872-1970). São Paulo: Instituto de Pesquisas Econômicas, 1984; FERREIRA, Lusirene Celestino França. Nas asas da imprensa: a repercussão da abolição da escravatura na província do Ceará nos periódicos do Rio de Janeiro (1884-1885). Dissertação (Mestrado em História) — Departamento de Ciências Sociais, Universidade Federal de São João del-Rei, São João del-Rei, MG, 2010; BASSANEZI, Maria Silvia C. Beozzo. Migrantes no Brasil da segunda metade do século XIX. In: ENCONTRO NACIONAL DE ESTUDOS POPUlACIONAIS, 12., Caxambu. Anais... Belo Horizonte: Abep, 2000; NOZOE, Nelson. Os refugiados da seca: emigrantes cearenses, 1888-1889. São Paulo: NEHD, 2003; SOUZA, Itamar
} 
tos migraram também para a Baixada, contribuindo para a formação da população local. Como se sabe, no Nordeste a população livre, negra e parda, era mais antiga — já que o Sudeste concentrou a maior parte dos escravos no século XIX, sobretudo na segunda metade ${ }^{77}$ e, portanto, mais miscigenada, não só com brancos, mas também com índios.

O mais importante a ser aqui destacado é a agência da população preta e parda na busca pelo seu reconhecimento legal e de sua família, através da burocracia do Estado. Ao se registrar, na maior parte dos casos na fase adulta, muito provavelmente o declarante já era residente da região e contraíra matrimônio, o que representava certa estabilidade. Alexandre Gonçalves Barboza Júnior, lavrador casado com Adalgiza Travassos Barboza, natural de Mar de Espanha, no estado de Minas Gerais, na região do Vale do Paraíba, registrou no dia 14 de setembro de 1934 seus três filhos: José Maria Barboza (26/9/1917), Geraldo Travassos Barboza (5/12/1918) e Margarida Maria Barboza (2/9/1919). Aparentemente migrou inicialmente sozinho, e só posteriormente trouxe esposa e filhos, registrando todos no mesmo dia. ${ }^{78}$ Pelo fato de o registro civil de nascimento do "autodeclarante" possivelmente demonstrar sua estabilidade na região, é lícito supor que ele possa ter chegado ou no mesmo mês, ou em anos anteriores à chegada de sua família.

São diversos os casos que consegui acompanhar desde o nascimento, no Vale do Paraíba, até o registro na Baixada. Encontrei, por exemplo, homens na fase adulta e provavelmente solteiros que migraram para a Baixada entre os anos de 1934 e 1939, entre os quais destaco o caso de Gil. No dia 14 de dezembro de 1917, Agostinho Alves de Amorim e sua esposa, Brígida Alves de Amorim, batizaram Gil na igreja de Santa Isabel do Rio Preto, distrito do município de Valença, nascido no dia 17 de setembro do mesmo ano. ${ }^{79}$ Ele provavelmente migrou ainda jovem para a Baixada Fluminense, pois aos 22 anos se dirigiu ao Cartório de Registro Civil de Nova Iguaçu para declarar seu nascimento. Já se autodenominando Gildo Alves de Amorim, deixou expressa sua cor, preta, assim como o nome dos avós paternos: Álvaro de Amorim e Eliza de Amorim; e maternos: Pedro Américo de Amorim e Maria da Conceição. ${ }^{80}$

Pode-se apontar a busca mais incessante, por esses migrantes, do registro civil de nascimento como consequência de sua estabilidade, da necessidade de formalizar seu emprego. O aumento de "autodeclarantes" em 1934 pode ser explicado em parte pela promulgação e divulgação de novos direitos conquistados pelos trabalhadores através da constituição daquele ano. Nada, porém, parece ter incentivado mais os empregadores a regularizarem seus proletários do que a criação da Justiça do Trabalho, no mesmo ano. ${ }^{81}$

de; FILHO, João Medeiros. Os degredados filhos da seca. Petrópolis: Vozes, 1984; THEOPHILO, R. Seccas do Ceará (segunda metade do século XIX). Fortaleza: Louis Cholowiesçki, 1909.

${ }^{77}$ SALLES, Ricardo. E o vale era escravo: Vassouras, século XIX, senhores e escravos no coração do Império. Rio de Janeiro: Civilização Brasileira, 2008.

${ }_{78}$ Registro Civil de Nascimento de Nova Iguaçu (RCN), livro 49, reg. 6222, 6223 e 6224, de 14/9/1934.

${ }^{79}$ Arquivo Eclesiástico da Igreja de Santa Isabel do Rio Preto, livro: s/n, assento, 226, p. 185, de 1917 (Aesirp).

${ }^{80}$ Registro Civil de Nascimento de Nova Iguaçu (RCN), livro 60, reg. 14.880, do ano de 1939.

${ }^{81}$ CARVALHO, José Murilo de. Cidadania no Brasil: um longo caminho. Rio de Janeiro: Zahar, 2000. 
O cruzamento dessa experiência com os demais registros civis demonstra que nos primeiros anos de migração houve uma predominância masculina na Baixada Fluminense. Em 1934, as mulheres correspondiam a apenas $15 \%$ dos migrados, para $85 \%$ de homens. Já no ano de análise seguinte, 1939, a quantidade de mulheres aumentou 32\% para 68\% de homens. A razão de masculinidade entre todos os migrantes é muito maior em 1934, atingindo um número de 594,7, e no ano de 1939 passa para 206,5. Apesar de um número maior de homens migrando, é mister salientar que, por mais que os homens tenham sido os pioneiros na migração, as mulheres também fizeram esse empreendimento. Não é novidade a migração desse grupo mesmo antes da abolição, pois, de acordo com Jean Lebrum:

As mulheres do século XIX movem-se mais do que se pensa. Participam das migraçóes camponesas vindas como domésticas ou costureiras, burguesas médias contratadas como preceptoras, não raro muito longe de seu país. Elas viajam e (às vezes) exploram. O mundo muda, modificam-se as fronteiras, mas também os sexos. ${ }^{82}$

Ou seja, nem sempre as mulheres tenderam a migrar na companhia ou em função dos seus cônjuges. Sua migração tem características próprias, nem sempre associadas ao processo desenvolvimentista de uma região.

\section{Conclusão}

A migração em massa não ocorreu no imediato pós-abolição. De acordo com a análise dos registros civis de nascimento, a maior parte dos migrantes chegou ao final da década de 1930. Ao cruzar essa informação com as entrevistas realizadas por Ana Rios, é possível afirmar que a migração definitiva do Vale do Paraíba para a Região Metropolitana da cidade do Rio de Janeiro ocorreu entre as décadas de 1920 e 1940 e foi empreendida por jovens nascidos nos anos posteriores à abolição — em sua maioria homens e solteiros. Tomando a migração como estratégia ativa de melhora de vida, e não como um resultado da desestruturação familiar, é possível observar outra configuração nesse processo vivenciado por descendentes diretos ou não de ex-escravizados: optaram por residir nas periferias da cidade do Rio de Janeiro, com destaque para área metropolitana, conhecida como Baixada Fluminense - uma região em ascensão onde era possível aliar o trabalho na lavoura com outros setores também importantes para a mobilidade social, como as escolas.

\footnotetext{
${ }^{82}$ LEBRUN, Jean. Palavras de mulheres. In: PERROT, Michelle. Mulheres públicas. São Paulo: Unesp, 1998 apud SILVA, Lucia Helena Oliveira. Construindo uma nova vida: migrantes paulistas afrodescendentes na cidade do Rio de Janeiro no pós-abolição (1888-1926). op. cit., p. 104.
} 
Contudo, muitas questóes ainda não foram respondidas sobre a história das migraçóes negras no Brasil, tais como: o papel da imprensa tanto na coibição da migração quanto no incentivo, nas décadas seguintes; a disputa de mercado de trabalho com os regionais; os conflitos gerados por essa chegada em massa de trabalhadores; os locais de moradia; o acesso à educação pelos migrantes, entre outras questôes que abordaremos em artigos futuros. $\mathrm{Ou}$ seja, ainda há muito sobre o que pesquisar nas experiências das migraçóes negras do pós-abolição brasileiro.

\section{Referências bibliográficas}

BASSANEZI, Maria Silvia C. Beozzo. Migrantes no Brasil da segunda metade do século XIX. In: ENCONTRO NACIONAL DE ESTUDOS POPULACIONAIS, 12., Caxambu. Anais... Belo Horizonte: Abep, 2000.

BERRY, Chad. Southern migrants, northern exiles. Urbana, IL: University of Illinois Press, 2000.

BEZERRA, Nielson. A cor da Baixada: escravidão, liberdade e pós-abolição no recôncavo da Guanabara. Duque de Caxias, RJ: APPH-CLIO, 2012.

CARVALHO, José Murilo de. Cidadania no Brasil: um longo caminho. Rio de Janeiro: Zahar, 2000.

. Os bestializados: o Rio de Janeiro e a República que não foi. São Paulo: Companhia das Letras, 1987.

CORREIA, Margarita. A discriminação racial nos dicionários de língua: tópicos para discussão, a partir de dicionários portugueses contemporâneos. Revista Alfa. v. 50, n. 2, p. 155171, jul./dez. 2006.

CRUZ, Maria Cecília Velasco e. Tradições negras na formação de um sindicato: Sociedade de Resistência dos Trabalhadores em Trapiche e Café, Rio de Janeiro, 1905-1930. Afro-Ásia, n. 24, p. 243-290, 2000.

DEAN, Warren. Rio Claro: um sistema brasileiro de grande lavoura, 1820-1920. Rio de Janeiro: Paz e Terra, 1977.

FARIA, Sheila de Castro. A colônia em movimento: fortuna e família no cotidiano colonial. Rio de Janeiro: Nova Fronteira, 1998.

FERREIRA, Lusirene Celestino França. Nas asas da imprensa: a repercussão da abolição da escravatura na província do Ceará nos periódicos do Rio de Janeiro (1884-1885). Dissertação (Mestrado em História) - Departamento de Ciências Sociais, Universidade Federal de São João del-Rei, São João del-Rei, MG, 2010.

FONER, Eric. O significado da liberdade. Revista Brasileira de História, v. 8, p. 14, 1988. 
FRAGA, Walter Fraga. Encruzilhadas da liberdade: histórias de escravos e libertos na Bahia (1870-1910). Campinas: Unicamp, 2006.

. Encruzilhadas da liberdade: histórias de escravos e libertos na Bahia (1870-1910). Campinas: Unicamp, 2006.

FRAGOSO, João. Baróes do café e sistema agrário escravista: Paraíba do Sul/Rio de Janeiro (1830-1888). Rio de Janeiro: 7 Letras, 2013.

GRAHAM, D. H.; FILHO, S. B. H. Migraçóes internas no Brasil (1872-1970). São Paulo: Instituto de Pesquisas Econômicas, 1984.

GREGORY, James N. The southern diaspora and the urban dispossessed: demonstrating the census public use microdata samples. The Journal of American History, v. 82, n. 1 p. 111 134, jun. 1995.

. The southern diaspora: how the great migrations of black and white southerners transformed America. Chapel Hill: University of North Carolina Press, 2005.

GROSSMAN, James R. Land of hope: Chicago, blacksoutherners, and the great migration. Chicago, IL: University of Chicago Press, 1989.

GUIMARÃES, Eliose Silva. Terra de preto: usos e ocupação da terra por escravos e libertos (Vale do Paraíba Mineiro, 1850-1920). Niterói: EdUFF, 2009.

HARRISON, Alferdteen. Black exodus: the great migration from the American South. Jackson e Londres: University Press of Mississipi, 1991.

HENRI, F. Black migration: movement north, 1900-1920. Garden City, NY: Anchor, 1975. HOLT, Thomas. The problem of freedom: race, labor, and politics in Jamaica and Britain, 1832-1938. Baltimore: Johns Hopkins University Press, 1992.

JOHNSON, D. M.; REX, R. C. Black migration in America: a social demographic history. Durham, NC: Duke University Press, 1981.

LEMANN, Nicholas. The promised land: the great migration and how it changed America. Nova York: Knopf, 1991.

LIEBERSON, Stanley; WILKINSON, Christy A. A comparison between northern and southern blacks residing in the north. Demography, n. 13, p. 199-224, 1976.

LIMA, Carlos A. M. Pequena diáspora: migraçôes de libertos e de livres de cor (Rio de Janeiro, 1765-1844). Locus: Revista de História, Juiz de Fora, v. 6, n. 2, p. 99-110, 2000.

LIMA, Henrique Espada. Sob domínio da precariedade: escravidão e os significados da liberdade de trabalho no século XIX. Topoi, v. 6, n. 11, p. 289-326, jul./dez. 2005.

LOPES, Nei. O negro no Rio de Janeiro e sua tradição musical: partido-alto, calango, chula e outras cantorias. Rio de Janeiro: Pallas, 1992.

MARQUES, Leonardo. Por ai e por muito longe: dívidas, migraçóes e os libertos de 1888.

Rio de Janeiro: Apicuri, 2009. 
MARTINS, J. S. O tempo da fronteira: retorno à controvérsia sobre o tempo histórico da frente de expansão e da frente pioneira. Tempo Social: revista de Sociologia da USP, São Paulo, v. 8, n. 1, p. 25-70, maio 1996.

MARTINS, Ronaldo Luiz. Mercadão de Madureira: caminhos do comércio. Rio de Janeiro: Condomínio do Entreposto Mercado do Rio de Janeiro, 2009.

MATOSO, Rafael. Echos de resistência suburbana: uma análise comparativa das contradições socioespaciais cariocas a partir das experiências dos moradores da Freguesia de Inhaúma (1900-1903). Dissertação (Mestrado) — Universidade Federal do Rio de Janeiro, Rio de Janeiro, 2009.

MATTOS, Hebe. Das cores do silêncio: significados da liberdade no Brasil escravista. Rio de Janeiro: Nova Fronteira, 1997.

MATTOS, Marcelo Badaró. Escravizados e livres: experiências comuns na formação da classe trabalhadora carioca. Rio de Janeiro: Bom Texto, 2008.

. Trajetórias entre fronteiras: o fim da escravidão e o fazer-se da classe trabalhadora no Rio de Janeiro. Revista Mundos do Trabalho, v. 1, n. 1, p. 51-64, jan./jun. 2009.

MONSMA, Karl. Histórias de violência: inquéritos policiais e processos criminais como fontes para o estudo de relaçóes interétnicas. In: DEMARTINI, Zeila de Brito Fabri; MONSMA, Karl. Linchamentos raciais depois da abolição: quatro casos do interior paulista. In: CONGRESSO INTERNACIONAL DA LATIN AMERICAN STUDIES ASSOCIATION, XXVIII., 2009, Rio de Janeiro. Anais... Rio de Janeiro: Lasa, 2009.

NASCIMENTO, Álvaro. 13 de Maio: memória da escravidão e educação nas páginas do Correio da Lavoura (Nova Iguaçu, RJ, 1917-1950). In: FORTES, Alexandre. Cruzando fronteiras: novos olhares sobre a história do trabalho. São Paulo: Fundação Perseu Abramo, 2013.

- A ressaca da marujada: recrutamento e disciplina na Armada Imperial. Rio de Janeiro: Arquivo Nacional, 2001.

. Francisco Madeira, a visibilidade de um comerciante negro no pós-abolição: economia e mobilidade em Nova Iguaçu. In: SIMPÓSIO NACIONAL DE HISTÓRIA, XVII. 2013. Natal, RN. Anais... São Paulo: Anpuh, 2013.

Qual a condição social dos negros no Brasil depois do fim da escravidão? O pós-abolição no ensino de história. In: SALGUEIRO, Maria Aparecida Andrade (Org.). A República e a questão do negro no Brasil. Rio de Janeiro: Museu da República, 2005.

NOZOE, Nelson. Os refugiados da seca: emigrantes cearenses, 1888-1889. São Paulo: NEHD, 2003.

PEREIRA, Waldick. Cana, café e laranja: história econômica de Nova Iguaçu. Rio de Janeiro: FGV, 1977. 
POPINIGIS, F. Proletários de casaca: trabalhadores no comércio (Rio de Janeiro, 18501920). Campinas: Unicamp, 2007.

RIOS, Ana Lugão; MATTOS, Hebe. Memórias do cativeiro: família, trabalho e cidadania no pós-abolição. Rio de Janeiro: Civilização Brasileira, 2005.

SALLES, Ricardo. E o vale era escravo: Vassouras, século XIX, senhores e escravos no coração do Império. Rio de Janeiro: Civilização Brasileira, 2008.

SCOTT, Rebecca. Defining the boundaries of freedom in the world of cane: Cuba, Brazil, and Louisiana after emancipation. The American Historical Review, v. 99, n. 1, p. 70-102, Feb. 1994.

. Emancipação escrava em Cuba: a transição para o trabalho livre, 1860-1889. Rio de Janeiro: Paz e Terra; Campinas: Unicamp, 1991.

SENRA, Nelson de Castro. História das estatísticas brasileiras. Rio de Janeiro: IBGE, 2006. v. 2. SILVA, Lucia Helena Oliveira. Construindo uma nova vida: migrantes paulistas afrodescendentes na cidade do Rio de Janeiro no pós-abolição (1888-1926). Tese (Doutorado em História) - Universidade Estadual de Campinas, Campinas, 2001.

SOUZA, Itamar de; FILHO, João Medeiros. Os degredados filhos da seca. Petrópolis: Vozes, 1984.

SOUZA, Sonali Maria de. Da laranja ao lote: transformações sociais em Nova Iguaçu. Dissertaçáo (Mestrado em Antropologia Social) - Museu Nacional, Universidade Federal do Rio de Janeiro, Rio de Janeiro, 1992.

THEOPHILO, R. Seccas do Ceará (segunda metade do século XIX). Fortaleza: Louis Cholowiesçki, 1909.

TOLNAY, Stewart E. Migration experience and family patterns in the 'promised land'. Journal of Family History, n. 23, p. 68-89, 1998.

. The African American 'great migration' and beyond. Annual Review of Sociology, v. 29, p. 209-232, 2003.

. The great migration and changes in the northern black family, 1940 to 1990. Social Forces, n. 75, p. 1213-1238, 1997.

. The great migration gets underway: a comparison of black southern migrants and non-migrants in the north, 1920. Social Science Quarterly, p. 235-252, 2001.

TOLNAY, Stewart E.; BECK, E. M. A festival of violence: an analysis of southern lynchings, 1882-1930. Urbana, IL: University of Illinois Press, 1995.

TOLNAY, Stewart E.; BECK, E. M. Racial violence and black migration in the South, 1910 to 1930. American Sociological Review, v. 57, n. 1, p. 103-116, Feb. 1992.

TROTTER JR., Joe William. The great migration in historical perspective: new dimensions of race, class \& gender. Bloomington and Indianapolis: Indiana University Press, 1991. 
TRUZZI, Oswaldo M. Serra (Orgs.). Estudos migratórios: perspectivas metodológicas. São Carlos: EDUFSCar, 2005.

WOOFTER, T. J. Negro problems in cities. Nova York: Doubleday, Doran \& Co., 1928. 